Iwona Chmura-Rutkowska

https://doi.org/10.26881/pwe.2018.43.04

ORCID: 0000-0002-9319-7767

Uniwersytet im. Adama Mickiewicza w Poznaniu

ichmurka@amu.edu.pl

Joanna Ostrouch-Kamińska

ORCID: 0000-0002-8211-740X

Uniwersytet Warmińsko-Mazurski

joanna.ostrouch@uwm.edu.pl

\title{
Edukacja dzieci do partnerstwa kobiet i mężczyzn jako sposób na przeciwdziałanie przemocy ze względu na płeć
}

\section{Summary \\ Education of children to equality of women and men as a way to prevent gender-based violence}

Gender-based violence is understood as violence motivated by gender stereotypes and prejudices resulting from normative expectations related to femininity and masculinity dominating in society and culture, and from unequal power relations between women and men. The aim of the article is to analyze the problem of gender-based violence in the context of its social and cultural sources, as well as ways to prevent it. The authors put forward a thesis that the main preventive measure is the education of children and youth to equality of women and men, both in public life and in the family, as well as the elimination of prejudices and unjust stereotypes related to gender from education.

Keywords: gender-based violence, gender stereotypes in education of children and youth, equality of women and men, gender socialization

Słowa kluczowe: przemoc ze względu na płeć, stereotypy płci w edukacji dzieci i młodzieży, partnerstwo kobiet i mężczyzn, socjalizacja rodzajowa

\section{Wprowadzenie}

Obecnie coraz częściej podkreśla się, iż edukacja zgodna ze stereotypowym podziałem ról i zadań ze względu na płeć nie tylko przestaje być adekwatna do wymogów współczesnych globalnych społeczeństw i rynku pracy, ale także do potrzeb, aspiracji i wyborów dokonywanych dziś przez kobiety i mężczyzn, przez co coraz bardziej oddala się od świata, w którym oni na co dzień funkcjonują (Ostrouch-Kamińska 2016). A coraz częściej funkcjonują lub deklarują chęć funkcjonowania w rodzinach partnerskich, opartych na równoważnym wkładzie obojga rodziców w życie rodzinne, w tym opiekę i wychowanie dzieci oraz w życie zawodowe. 
Innym argumentem na rzecz zmian w edukacji dzieci i młodzieży w stronę partnerstwa kobiet i mężczyzn jest ich rosnąca niezgoda na niesprawiedliwe i krzywdzące podziały istniejące $\mathrm{w}$ różnych przestrzeniach życia społecznego oraz potrzeba podjęcia działań na rzecz przeciwdziałania i zwalczania dyskryminacji oraz przemocy w relacjach obu płci. Dotyczy to zarówno przemocy w bliskich związkach i w rodzinie - głównie wobec kobiet, dzieci, osób starszych lub z niepełnosprawnością, ale także przemocy rówieśniczej czy w relacjach zawodowych. Skoro podstawą relacji przemocowych jest nierówność podmiotów tych relacji czy wręcz uprzedmiotowienie jednej ze stron, to edukacja do partnerstwa kobiet i mężczyzn wydaje się być tym sposobem interwencji, dzięki któremu będzie możliwe budowanie większej równowagi pozycji w relacjach dziewcząt i chłopców oraz kobiet i mężczyzn, a w konsekwencji również wyższej jakości relacji obu płci i bardziej demokratycznego społeczeństwa.

\section{Przemoc ze względu na płeć}

Brak równości płci jest konsekwentnie wskazywany jako podstawowy czynnik determinujący każdego rodzaju przemoc wobec dziewcząt i kobiet, zarówno w bliskich związkach, jak i w sferze publicznej. Dowodów dostarczają liczne międzynarodowe badania i metaanalizy, jak również codzienne doświadczenie z pracy ekspertów i ekspertek zajmujących się na całym świecie profilaktyką i interwencjami w sytuacji przemocy (Fulu i in. 2013; Heise 1998; Jewkes 2002; Nayak i in. 2003; Ridgeway, Correll 2004; WHO 2005; WHO 2009; Krug i in. 2002).

Wyrazem wagi, skali i specyfiki problemu jest pojawienie się w obiegu międzynarodowym pojęcia „przemoc ze względu na płeć” (gender-based violence GBV oraz sexual and gender-based violence $S G B V$ ), która jest rozumiana jako przemoc motywowana stereotypami i uprzedzeniami związanymi z płcią, a zatem wynika z normatywnych oczekiwań związanych z kobiecością i męskością dominujących w danym społeczeństwie i kulturze oraz z nierównych relacji władzy pomiędzy płciami (Bloom 2008: 14; UNHCR 2011; UNESCO, UN Women 2016; UN Women 2018). Termin ten odnosi się do każdego krzywdzącego, przynoszącego szkodę działania, które jest dokonywane wbrew woli jednej osoby i które jest oparte na przekonaniach dotyczących płci, cechach przypisywanych ze względu na płeć oraz na przekonaniach dotyczących różnic między mężczyznami i kobietami. Przemocą ze względu na płeć są wszystkie akty, których skutkiem jest cierpienie i szkoda fizyczna, psychiczna lub seksualna. Należą do niej także groźby, przymuszanie i inne formy pozbawiania praw i wolności, niezależnie od tego, czy występują w życiu publicznym, czy prywatnym. Najbardziej rozbudowaną definicję formalnoprawną przemocy ze względu na płeć znajdziemy w dokumentach i aktach Rady Europy i Unii Europejskiej. Dyrektywa Parlamentu Europejskiego i Rady Europy z dnia 25 października 2012 r. określa przemoc ze względu na płeć jako „przemoc, która jest skierowana przeciwko osobie ze względu na jej płeć, tożsamość płciową lub ekspresję płciową lub której ofiarami stają się w przeważającej mierze osoby danej płci. (...) Może ona powodować 
krzywdę o charakterze fizycznym, seksualnym, emocjonalnym lub psychologicznym lub szkodę o charakterze ekonomicznym. Przemoc ze względu na płeć jest rozumiana jako forma dyskryminacji oraz pogwałcenie podstawowych wolności ofiary i obejmuje przemoc w bliskich związkach, przemoc seksualną (w tym gwałt, napaść na tle seksualnym i molestowanie seksualne), handel ludźmi i niewolnictwo oraz różne formy krzywdzących praktyk, takie jak przymusowe małżeństwa, okaleczanie żeńskich narządów płciowych i tak zwane przestępstwa popełniane ' $w$ imię honoru'. Kobiety będące ofiarami przemocy ze względu na płeć oraz ich dzieci często wymagają szczególnego wsparcia i szczególnej ochrony ze względu na występujące w przypadku takiej przemocy wysokie ryzyko wtórnej oraz ponownej wiktymizacji, zastraszania i odwetu" (Parlament Europejski 2012).

Przemoc ze względu na płeć przejawia się we wszystkich znanych formach przemocy, zarówno bezpośrednich, jak i pośrednich, werbalnych i pozawerbalnych, jako przemoc fizyczna, psychologiczna, relacyjna, seksualna czy wreszcie cyberprzemoc. Dotyczy relacji międzyludzkich, praktyk i zasad funkcjonowania instytucji oraz symbolicznych ram kultury. We wszystkich regionach świata przemocy motywowanej uprzedzeniami związanymi z płcią w roli ofiary doświadczają przede wszystkim dziewczęta i kobiety oraz także (jednak w zdecydowanie mniejszym stopniu) chłopcy i mężczyźni (Gruszczyńska 2007). W związku z tym, że przemoc ze względu na płeć w przeważającej liczbie przypadków jest powodowana przez mężczyzn i skierowana przeciwko dziewczętom i kobietom, w wielu opracowaniach na nich właśnie skupiona jest uwaga i do nich skierowana jest większość instytucjonalnych działań i programów. W „Deklaracji o eliminacji przemocy wobec kobiet”, podjętej przez Zgromadzenie Ogólne na Konferencji Praw Człowieka w Wiedniu w 1993 r. ${ }^{1}$ przemoc wobec kobiet zdefiniowana jest ,jako wszelki akt przemocy związany z faktem przynależności danej osoby do określonej płci, którego rezultatem jest lub może być fizyczna, seksualna lub psychiczna krzywda lub cierpienie kobiet, włącznie z groźbą popełnienia takich czynów, wymuszeniem lub arbitralnym pozbawieniem wolności, niezależnie od tego, czy czyny te mają miejsce w życiu publicznym czy prywatnym" (ONZ 1993, art. 1).

Niezależnie od tego, jak szeroko lub wąsko definiowana jest przemoc ze względu na płeć, wśród ekspertek i ekspertów tej problematyki istnieje zgoda, że źródłem krzywdzących zachowań oraz łamania praw człowieka są nierówne stosunki między płciami i nadużycia władzy. Może to przybrać formę przemocy seksualnej w bliskim związku, prześladowania ze strony rówieśników w szkole, może być również dyskryminacją wbudowaną w przepisy prawa, obowiązujące normy obyczajowe lub praktyki społeczne. Tworzenie bezpiecznych środowisk i ograniczanie ryzyka można osiągnąc jedynie poprzez rozwiązanie problemu nierówności płci i dyskryminacji.

1 Deklaracja stanowi uzupełnienie i wzmocnienie Konwencji w sprawie likwidacji wszelkich form dyskryminacji kobiet (Convention on the Elimination of All Forms of Discrimination against Women, CEDAW) przyjętej przez Zgromadzenie Ogólne Narodów Zjednoczonych dnia 18 grudnia 1979 r. 


\section{Socjalizacja różnicująca zgodna ze stereotypem a przemoc ze względu na płeć}

Socjalizacja rodzajowa jest determinowana zarówno przez czynniki makrospołeczne (struktura ekonomiczna, socjalna, polityczna, kulturalna oraz wszystkie instytucje), jak również mikrospołeczne (interakcje: wychowanie, nauka, komunikowanie się z rówieśnikami, rodziną, kontakt z treściami medialnymi oraz cechy biologiczne i psychiczne samego podmiotu). Do czynników socjalizacyjnych zaliczyć można zatem wzorce zachowania, wzory osobowe i modele, wymagania i zadania, oczekiwania społeczne i nakazy ról, stereotypy, dychotomie oraz wartości i normy kulturowe związane z płcią. Wskazuje się również na liczne mechanizmy socjalizacyjne, takie jak: naśladownictwo, identyfikacja, modelowanie, uczenie się, system wzmocnień, pełnienie ról społecznych i internalizacja (Pankowska 2005).

W procesie socjalizacji rodzajowej człowiek dostrzega wyraźną dychotomię kobiecość - męskość, która ma z jednej strony znaczenie adaptacyjne, ponieważ ułatwia określenie miejsca i roli w społeczeństwie, z drugiej zaś - staje się przeszkodą w rozwoju i samorealizacji. Badania wskazują, że większe szanse rozwojowe i powodzenie w rolach społecznych w dorosłości mają jednostki, które wykraczają poza stereotypowe wyobrażenia roli płciowej (Miluska 1996; Mandal 2000; Bem 1996; Brannon 2002). Z kolei przekazy mieszane, sprzeczne, nieokreślone z jednej strony stanowią szeroką ofertę możliwości wyboru, z drugiej - poczucie iluzji, że taki wybór jest w ogóle możliwy. O ile bowiem sprzeczne i nieprawdziwe wyobrażenia mogą bezkonfliktowo istnieć na poziomie kulturowych oczekiwań wobec roli, to próba ich realizacji w rzeczywistości będzie powodowała frustracje i konflikty. Wreszcie socjalizacyjne przekazy egalitarne, związane z ideologią równych praw oraz równych możliwości z jednej strony oskarżane są o kształtowanie idei emancypacji od tradycyjnych wzorów i ról płciowych zgodnie z ,męskim” kanonem wartości i na „męskich zasadach”, z drugiej - promując ideę wymiany ról, wykraczanie poza stypizowane płciowo role lub integrację cech tradycyjnie uznawanych za męskie i kobiece niezależnie od płci biologicznej, zmuszają do nieustannego redefiniowania tego, kim jesteśmy jako kobiety i mężczyźni oraz wypracowania kompetencji w zakresie rozumienia i wykorzystywania potencjału wykraczającej poza tradycyjny schemat zintegrowanej pod względem płci tożsamości (Gromkowska-Melosik 2011; Bem 2000).

Trening odmiennego ze względu na płeć myślenia i zachowania zaczyna się już we wczesnym dzieciństwie. Dzieci rozwijają swoją tożsamość, identyfikując pod wpływem otoczenia społecznego pewne cechy i zachowania jako „kobiece” lub „męskie”, budując w ten sposób ,schemat rodzaju”. Uczą się stereotypów w procesie socjalizacji - poprzez bezpośrednie doświadczenia zdobywane w rodzinie i innych grupach o charakterze formalnym i nieformalnym oraz w instytucjach powołanych do wychowania i edukacji. Istotne znaczenie ma także przekaz symboliczny zawarty w mass mediach, literaturze, sztuce oraz treści przekazywane i wzmacniane przez systemy religijne (Chomczyńska-Miliszkiewicz 2002). Reprezentacje oraz definicje i znaczenia związane z kobiecością i męskością stanowią budulec dla konstruowania indywidualnej i społecznej tożsamości 
płciowej. Tożsamość płciowa to zarówno poczucie i świadomość przynależności do określonej grupy płciowej, wiedza o atrybutach, które określają w danej kulturze kobiecość i męskość, jak i znajomość przepisów i norm dotyczących zachowania (rola płciowa), często mających swe źródła w ich stereotypowych ujęciach (Miluska 1996: 23).

Stereotypy związane z płcią określa się jako „uproszczone sądy i koncepcje zachowania osobników żeńskich lub męskich, podzielane przez ogół danego społeczeństwa, uczone w procesie wzrastania i socjalizacji w tym społeczeństwie" (Mandal 2000: 13). Wpływają one na przekonania, postawy, ale także na zachowania. Stereotypy związane z płcią wpływają na to, w jaki sposób ludzie kształtują pojęcie własnego ,ja”, a w konsekwencji, w jaki sposób o sobie myślą, prezentują się i oceniają. Dotyczą także sfery interpersonalnej - poprzez kierowanie różnych oczekiwań, w różnym traktowaniu oraz różnym interpretowaniu zachowań kobiet i mężczyzn (Mandal 2000). Według K. Deaux i L. Lewis (Deaux, Lewis 1984), stereotypy związane z płcią mają wieloczynnikową strukturę, w skład której wchodzą wyobrażenia dotyczące wyglądu, cech osobowości, zachowań i ról społecznych (w tym ról zawodowych). Deaux i Lewis dowiodły, że informacja o płci uruchamia w jednostce myślenie i przekonania dotyczące każdego z wymienionych komponentów. Równocześnie informacja na temat jednego z komponentów okazuje się często wystarczającym impulsem, by ludzie wyciągali wnioski na temat płci osoby, która je posiada a także pozostałych cech.

Stereotypy jako fakt psychologiczny stanowią rodzaj narzędzia poznania i orientacji w świecie, wpływając na ludzkie zachowania. Mają także wymiar społeczny, jako element składowy kultury wyznaczając wiele zrytualizowanych form życia społecznego. Liczne badania wskazują, że stanowią potencjalne źródło barier rozwojowych i ograniczają doświadczenia jednostki, często są nieprawdziwe, krzywdzące, negatywnie wpływają na relacje interpersonalne oraz są podstawą wielu konfliktów społecznych (Frable, Bem 1985; Mandal 2000; Bem 2000; Deaux, Kite 2002; Cross, Markus 2002). Stereotypy stanowią podstawę tworzenia negatywnych nastawień - uprzedzeń oraz są źródłem bodźców, usprawiedliwień i normalizowania dyskryminacyjnych zachowań, podtrzymywania nierówności oraz kanalizowania, ukierunkowywania i usprawiedliwiania wszystkich form przemocy (Macrae, Stangor, Hewstone 1999; Unger, Saundra 2002; Nelson 2003; Chmura-Rutkowska, Frąckowiak-Sochańska 2016). Szczególnie wartościowe są wyniki badań międzykulturowych i historycznych, ponieważ uwidaczniają, w jak różny sposób definiuje się kobiecość i męskość oraz jak różne kultury, a więc przekonania, wiedza, wartości i normy oraz praktyki wpływają na poziom przemocy ze względu na płeć i jaką rolę w tym procesie odgrywa stereotypowy porządek płci (Bourdieu 2004; Connell 2013).

\section{Stereotypowy porządek płci i przemoc jako nierówność podmiotów}

Przemoc pojawia się w różnych relacjach i jest możliwa wszędzie tam, gdzie istnieje różnica sił i rang (Helios, Jedlecka 2017). W takim ujęciu zjawiska przemocy podkreśla się nierówność podmiotów relacji oraz fakt, iż jest to świadome i intencjonalne krzywdzące 
zachowanie, które jest nadużyciem i wykorzystaniem swojej przewagi nad inną osobą dla uzyskania ważnego dla siebie celu lub korzyści. Przewaga ta może mieć różny charakter: przewagi fizycznej, liczebnej, psychologicznej, społecznej, sytuacyjnej lub kulturowej (symbolicznej). Przemoc ma nie tylko indywidualny i relacyjny, ale także społeczny i kulturowy wymiar oraz kontekst; może być jednorazowym, krótkotrwałym krzywdzącym zachowaniem i doświadczeniem. Może też polegać na świadomym, systematycznym, długotrwałym prześladowaniu, dręczeniu, gnębieniu, znęcaniu się i upokarzaniu. Niezależnie jednak od dotkliwości i długości trwania procederu, badacze i badaczki są zgodni, że osoby stosujące przemoc wykorzystują swoją przewagę, a ich celem jest bardzo często nie tyle krzywdzenie samo w sobie, ale możliwość kontrolowania innych oraz chęć uzyskania lub podtrzymania swojej dominującej pozycji i władzy (Monckton Smith i in. 2014; Helios, Jedlecka 2017). Stąd niezwykle ważną kwestią w analizie sytuacji jest wiedza dotycząca tożsamości i statusu społecznego osób doświadczających przemocy i ją stosujących. Badania dowodzą, że ludzie, którzy są ofiarami przemocy, bardzo często należą do pewnych szczególnych grup lub kategorii społecznych, usytuowanych na niskich szczeblach hierarchii społecznej lub uznawanych za słabsze.

Akceptacja dla nierówności, odbieranej jako „oczywisty” porządek społeczno-kulturowy oparty na przewadze jednych nad drugimi oraz możliwość narzucania przez grupy uprzywilejowane grupom podporządkowanym symboli i znaków oraz znaczeń, wzorców zachowań, przekonań, wartości i norm jest efektem, jak wskazuje P. Bourdieu, działania ukrytej przemocy symbolicznej, która reprodukuje społeczne dystanse i uprawomocnia każdą przemoc bezpośrednią (Bourdieu, Wacquant 2001; Bourdieu 2004; Kopciewicz 2005). Stereotypy związane z płcią w tej perspektywie same w sobie stanowią zatem narzędzie ,przemocy symbolicznej” w rozumieniu władzy i kontroli społecznej, ponieważ opisując to, jaka osoba danej płci ,jest” (element deskryptywny) i jaka ,powinna/musi być" (element normatywny), kontrolują, ograniczają (lub uniemożliwiają) możliwości wyboru zachowań, a w szerszej perspektywie socjalizacji i wychowania, rozwój jednostki.

Przemoc ze względu na płeć (w tym przemoc seksualna) jest globalnym problemem, określanym jako „epidemia” oraz łamanie podstawowych praw człowieka. W takim kontekście coraz częściej analizuje się przemoc w bliskich relacjach, w tym przemoc domową. E. Stark, autor koncepcji przemocy zwanej „zniewolenie i kontrola” postuluje, by różne formy przemocy domowej, przemocy w bliskich relacjach kobiet i mężczyzn traktować nie tylko jako przestępstwa kryminalne, ale właśnie jako łamanie praw człowieka (Stark 2007). Stark twierdzi, że w czasach dynamicznych zmian społecznych narasta przemoc wobec kobiet, której źródłem jest chęć utrzymania przywilejów przez mężczyzn, wynikająca z ich kulturowej dominacji oraz chęci opóźnienia zmiany w dotychczasowym porządku płci. Formy tej przemocy to przede wszystkim różne strukturalne sposoby wykorzystywania, nakazów, domagania się posłuszeństwa poprzez narzucanie własnej woli, ograniczanie możliwości wyboru i pozbawianie wsparcia w realizacji własnych dążeń (Szymkiewicz 2009). Jak podaje B. Szymkiewicz, przeciwdziałanie ,zniewoleniu i kontroli” powinno obejmować szereg działań skierowanych w stronę upodmiotowienia kobiet 
w relacjach z mężczyznami i zmiany krzywdzących stereotypów ról płciowych, uniemożliwiających realizację praw kobiet do autonomii.

\section{W stronę przeciwdzialania przemocy ze względu na pleć - edukacja dziewcząt i chłopców do partnerstwa}

Uznanie wagi wyników badań wskazujących na nierówności płci jako głównego czynnika ryzyka przemocy ze względu na płeć wobec dziewcząt i kobiet spowodowało, że praca na rzecz równości płci jest obecnie strategicznym celem polityk różnego szczebla w wielu krajach oraz w organizacjach ponadnarodowych, takich jak agendy Organizacji Narodów Zjednoczonych: UNESCO, UNICEF, UNFPA, UN Women czy Światowa Organizacja Zdrowia, Bank Światowy, Rada Europy i Unia Europejska. W wielu dokumentach i raportach przygotowywanych przez powyższe instytucje podkreśla się związek między przesądami i stereotypami związanymi z płcią a przemocą, wskazując jednocześnie, że odrzucająca tradycyjne uprzedzenia i patriarchalizm edukacja jest narzędziem zmiany i nadzieją na bardziej sprawiedliwy i wolny od przemocy świat. Deklaracja o eliminacji przemocy wobec kobiet ONZ uznaje wprost, że „przemoc wobec kobiet jest manifestacją historycznej nierówności w relacjach między płciami, która doprowadziła do dominacji mężczyzn i dyskryminacji kobiet oraz stanęła na drodze do ich pełnego rozwoju, a także że przemoc wobec kobiet jest podstawowym mechanizmem społecznym, przy pomocy którego kobiety są zmuszane do podległości wobec mężczyzn” (ONZ 1993). W art. 4. wskazuje się równocześnie na fundamentalną rolę edukacji w przeciwdziałaniu przemocy, której zadaniem jest krytyczna analiza i eliminacja z procesów wychowania i kształcenia stereotypów związanych z przekonaniem o podrzędności jednej płci i uprzedzeń związanych z płcią (ONZ 1993). Na krzywdzące stereotypy związane z płcią, nierówność płci oraz męską dominację jako źródło przemocy wskazuje także „Konwencja Rady Europy o zapobieganiu i zwalczaniu przemocy wobec kobiet i przemocy domowej”, ratyfikowana przez Polskę w 2015 roku. Czytamy w niej, iż wdrażanie „równości kobiet i mężczyzn ma zasadnicze znaczenie dla zapobiegania przemocy wobec kobiet, uznając, że przemoc wobec kobiet jest przejawem nierównych stosunków władzy między kobietami a mężczyznami” (Rada Europy 2011). Zgodnie z tym traktatem państwo ma obowiązek zapobiegania przemocy wobec kobiet między innymi poprzez niwelowanie $z$ edukacji uprzedzeń i krzywdzących stereotypów związanych z płcią oraz prowadzenie edukacji na rzecz większego partnerstwa kobiet i mężczyzn (UNICEF 2010).

W przeciwieństwie do instytucji edukacyjnych, które wciąż są ostoją mniej lub bardziej stereotypowego ujęcia społecznych ról związanych z płcią, edukacja dzieci do partnerstwa kobiet i mężczyzn pojawia się coraz częściej w rodzinach, co przekłada się na wymierne korzyści rozwojowe dziewcząt i chłopców. Wyniki badań (Sekaran 1986) pokazują, że dzieci z rodzin o bardziej partnerskim podziale zadań i ról pomiędzy rodzicami są kreatywne, mają wysokie poczucie własnej wartości, a to wpływa pozytywnie na ich rozwój. W porównaniu z dziećmi wychowywanymi w rodzinach o tradycyjnym podziale 
ról dzieci wychowywane przez oboje rodziców z ich porównywalnym zaangażowaniem są bardziej niezależne i szybciej się usamodzielniają, tworzą bliższe relacje z obojgiem rodziców, mają wyższe kompetencje społeczne i umiejętność rozpoznawania i zaspokajania potrzeb, osiągają wyższy stopień rozwoju moralnego, a także potrafią rozwijać głębsze więzi z płcią przeciwną, bez uprzedzeń i nastawień dyskryminacyjnych. Synowie, których łączyła silna więź nie tylko z matką, ale również z ojcem, są bardziej emocjonalni, potrafią okazywać uczucia, troskę i wsparcie i częściej deklarują, że chcą w przyszłości zostać ojcami. Córki mają wyższe poczucie własnej wartości i pewność siebie, co zwiększa ich szanse na osiągnięcie sukcesu (Balswick, Balswick 1995). Poprzez równe zaangażowanie zarówno chłopców, jak i dziewcząt w opiekę nad rodzeństwem, np. karmienie czy przewijanie, dzieci rozwijają umiejętności związane z partnerskim pełnieniem ról rodzicielskich. Obserwując rodziców - partnerów, doświadczają swoistej demokratycznej rzeczywistości rodzinnej, zarówno w sferze prywatnej, jak i zawodowej/decyzyjnej. Mają zatem większą szansę w przyszłości wyjść poza tradycyjną rolę męską czy kobiecą, bez ponoszenia tak wysokich kosztów emocjonalnych jak ich rodzice, a to mogłoby zbliżyć je do rozumienia reguł i funkcjonowania w małżeństwach partnerskich, zanim ideologia egalitaryzmu stałaby się rzeczywistością społeczną (Ostrouch 2005).

\section{Refleksje końcowe}

Chociaż wciąż brak uniwersalnego modelu wskazującego, które aspekty równości płci są najbardziej istotne dla zapobiegania przemocy, to istnieje zgoda co do tego, że kluczową kwestią, bez której przeciwdziałanie przemocy ze względu na płeć będzie utrudnione, są przekonania, stereotypy i uprzedzenia związane z kobiecością i męskością oraz przekonania dotyczące różnicy i nierówności związanych z płcią determinujące i uzasadniające hierarchię płci oraz dominację mężczyzn. Wydaje się więc, iż edukacja do partnerstwa kobiet i mężczyzn, do relacji dwupodmiotowej opartej na godności obu stron relacji i poszanowaniu praw obu płci, to najlepszy sposób na przeciwdziałanie przemocy w relacjach kobiet i mężczyzn oraz na zmniejszanie doświadczanych przez nich nierówności w kulturze i społeczeństwie.

Tymczasem normy i wartości wpisane w kulturową męskość i kobiecość są wciąż usprawiedliwieniem dla wielu form przemocy oraz przyjmowania ról sprawcy i ofiary. Dopóki w szerokiej świadomości społecznej będzie funkcjonowało przekonanie, iż okazywanie siły przez mężczyzn i budowanie relacji opartej na dominacji jest elementem odgrywania męskiej roli, a niesprzeciwianie się i podporządkowanie - kobiecej, dopóty trudno będzie wprowadzić do edukacji idee rzeczywistego partnerstwa kobiet i mężczyzn. Jak zauważa wiele badaczek i badaczy, to dotyczy nie tylko wzmacniania dziewcząt i zmiany stereotypów związanych z kobiecością, ale równocześnie, a być może przede wszystkim, konieczności zmiany wzorca męskości. Obecnie za największe wyzwanie oraz równocześnie owocną prewencję antyprzemocową uznaje się konstruktywną pracę z chłopcami. Badania wskazują na skuteczność wspierania psychofizyczne- 
go (w tym seksualnego) zdrowia oraz emocjonalnego i społecznego rozwoju chłopców przy równoczesnej edukacji pomagającej chłopcom krytycznie przyjrzeć się i zrozumieć wpływ ograniczających i krzywdzących stereotypów związanych z płcią. Równie ważne jest włączanie chłopców i mężczyzn w konkretne działania w roli sojuszników równości płci. Nie ma wątpliwości, że odejście od toksycznych i przemocowych skryptów męskości i danie chłopcom możliwości wyboru alternatywnej drogi rozwoju będzie miało pozytywny wpływ na ich życie, ale także na dobrostan całych społeczeństw (Connell 1987; UNFPA 2010; Ricardo i in. 2011; Katz 2012; Chmura-Rutkowska 2012). Dalsze niezauważanie bądź bagatelizowanie zakorzenionych w kulturze i praktykach społecznych przesłań dotyczących przemocy ze względu na płeć czyni i wciąż będzie czyniło wszelkie działania prewencyjne nieskutecznymi.

\section{Literatura}

Balswick J., Balswick J. (1995), The Dual-Earner Marriage: The Elaborate Act. Fleming H. Revell, Grand Rapids.

Bem S.L. (1996), Androgynia psychiczna a tożsamość płciowa. W: P.G. Zimbardo, F.L. Ruch (red.), Psychologia i życie. Warszawa, PWN.

Bem S.L. (2000), Męskość. Kobiecość. O różnicach wynikających z ptci. Gdańsk, GWP.

Bloom S. (2008), Violence against Women and Girls: A Compendium of Monitoring and Evaluation Indicators. Chapel Hill, The University of North Carolina at Chapel Hill.

Bourdieu P. (2004), Męska dominacja. Warszawa, Oficyna Naukowa.

Bourdieu P., Wacquant L.J.D. (2001), Zaproszenie do socjologii refleksyjnej. Warszawa, Oficyna Naukowa.

Brannon L. (2002), Psychologia rodzaju. Kobiety i mężczyźni: podobni czy różni? Gdańsk, GWP.

Chmura-Rutkowska I., Frąckowiak-Sochańska M. (2016), Psychospołeczne konsekwencje stereotypów związanych z płcią. W: I. Chmura-Rutkowska, M. Duda, M. Mazurek, A. Sołtysiak-Łuczak (red.), Gender w podręcznikach. Projekt badawczy. Raport. T. 1. Warszawa, Fundacja Feminoteka.

Chmura-Rutkowska I. (2012), Przemoc rówieśnicza w gimnazjum a płeć. Kontekst społeczno-kulturowy. „Forum Oświatowe”, 1 (46).

Chomczyńska-Miliszkiewicz M. (2002), Edukacja seksualna w społeczeństwie współczesnym. Konteksty pedagogiczne i psychospołeczne. Lublin, Wydawnictwo UMCS.

Connell R. (2013), Socjologia ptci. Płeć w ujęciu globalnym. Warszawa, PWN.

Connell R.W. (1987), Gender and power. Society, the person, and sexual politics. Cambridge, Polity Press.

Cross S.E., Markus H.R. (2002), Płeć w myśleniu, przekonaniach i działaniu: podejście poznawcze. W: B. Wojciszke (red.), Kobiety i mężczyźni: odmienne spojrzenia na różnice. Gdańsk, GWP.

Deaux K, Kite M. (2002), Stereotypy płci. W: B. Wojciszke (red.), Kobiety i mężczyźni: odmienne spojrzenia na różnice. Gdańsk, GWP.

Deaux K., Lewis L. (1984), Structure of gender stereotypes: Interrelationships among components and gender label. „Journal of Personality and Social Psychology”, 46 (5).

Frable D.E.S., Bem S.L. (1985), If you're gender-schematic, all members of the opposite sex look alike. „Journal of Personality and Social Psychology”, 49. 
Fulu F., Warner X., Miedema S., Jewkes R., Roselli T., Lang J. (2013), Why do some men use violence against women and how can we prevent it? Quantitative findings from the UN multicountry study on men and violence in Asia and the Pacific. Bangkok, UNDP, UNFPA, UN Women and UNV.

Gromkowska-Melosik A. (2011), Edukacja i (nie)równość społeczna kobiet. Studium dynamiki dostęu. Kraków, Oficyna Wydawnicza Impuls.

Gruszczyńska B. (2007), Przemoc wobec kobiet w Polsce. Aspekty prawno-kryminologiczne. Warszawa, Wolters Kulwer Polska.

Heise L. (1998), Violence against women, an integrated, ecological framework. „Violence Against Women", 4 (4).

Helios J., Jedlecka W. (2017), Wspótczesne oblicza przemocy. Zagadnienia wybrane. Wrocław, Wydawnictwo Uniwersytetu Wrocławskiego.

Jewkes R. (2002), Intimate partner violence: causes and prevention. „The Lancet”, 359 (20).

Katz J. (2012), Paradoks macho. Warszawa, Wydawnictwo Czarna Owca.

Kopciewicz L. (2005), Kobiecość, męskość i przemoc symboliczna. Polsko-francuskie studium porównawcze. Kraków, Oficyna Wydawnicza Impuls.

Krug E., Dahlberg L., Mercy J., Zwi A., Lozano R. (2002), World report on violence and health. Geneva, World Health Organization.

Macrae C.N., Stangor Ch., Hewstone H. (1999), Stereotypy i uprzedzenia. Gdańsk, GWP.

Mandal E. (2000), Podmiotowe i interpersonalne konsekwencje stereotypów zwiąanych z ptcia. Katowice, Wydawnictwo Uniwersytetu Śląskiego.

Miluska J. (1996), Tożsamość kobiet i mężczyzn w cyklu życia. Poznań, Wydawnictwo Naukowe UAM.

Monckton Smith J., Williams A., Mullane F. (2014), Domestic Abuse, Homicide and Gender. Strategies for Policy and Practice. Basingstoke, Palgrave Macmillan.

Nayak M., Byrne C., Martin M., Abraham A. (2003), Attitudes towards violence against women: A cross-nation study. „Sex Roles”, 49 (7/8).

Nelson T.D. (2003), Psychologia uprzedzeń. Gdańsk, GWP.

ONZ (1979), Konwencja w sprawie likwidacji wszelkich form dyskryminacji kobiet przyjęta przez Zgromadzenie Ogólne Narodów Zjednoczonych dnia 18 grudnia 1979 r., https://amnesty.org. pl/wp-content/uploads/2016/04/Konwencja-Likwidacja-dyskryminacji-kobiet.pdf (1.10.2018).

ONZ (1993), Deklaracja o eliminacji przemocy wobec kobiet z dnia 20 grudnia 1993 roku. Rezolucja 48/104 Zgromadzenia Ogólnego ONZ. http://libr.sejm.gov.pl/tek01/txt/onz/1993.html (1.10.2018).

Ostrouch-Kamińska J. (2016), Partnerstwo w relacji matżeńskiej jako wspótczesna wartość wychowania. „Problemy Wczesnej Edukacji”, 2 (33).

Ostrouch J. (2005), (Re)socjalizacja a edukacja w rodzinie o równoległych karierach rodziców (dual-career family). W: R. Leppert, Z. Melosik, B. Wojtasik (red.), Młodzież wobec (nie)gościnnej przyszłości. Wrocław, Wydawnictwo Naukowe DSWE.

Pankowska D. (2005), Wychowanie a role ptciowe. Gdańsk, GWP.

Parlament Europejski (2012), Dyrektywa Parlamentu Europejskiego i Rady 2012/29/UE z dnia 25 października 2012 r. ustanawiająca normy minimalne w zakresie praw, wsparcia i ochrony ofiar przestępstw oraz zastępujaca decyzję ramowa Rady 2001/220/WSiSW. https://eur-lex.europa. eu/legal-content/PL/TXT/?uri=celex\%3A32012L0029 (1.10.2018). 
Rada Europy (2011), Konwencja Rady Europy o zapobieganiu i zwalczaniu przemocy wobec kobiet i przemocy domowej, sporzadzona w Stambule dnia 11 maja 2011 r., Dz. U. 2015, pozycja 961, http://www.dziennikustaw.gov.pl/DU/2015/961 (1.10.2018).

Ricardo Ch., Eads M, Barker G. (2011), Engaging Boys and Young Men in the Prevention of Sexual Violence: A systematic and global review of evaluated interventions. Washington, Sexual Violence Research Initiative.

Ridgeway C., Correll S. (2004), Unpacking the gender system: A theoretical perspective on gender beliefs and social relations. „Gender and Society”, 18 (4).

Sekaran U. (1986), Dual-Career Families. Contemporary Organizational and Counseling Issues. San Francisco-London, Jossey-Bass Publishers.

Stark E. (2007), Coercive Control. How Men Entrap Women in Personal Life. New York, Oxford University Press.

Szymkiewicz B. (2009), Zniewolenie i kontrola. Przemoc domowa jako łamanie praw człowieka. „Niebieska Linia”, 5 (64).

UN Women (2018), Facts and figures: Ending violence against women, http://www.unwomen.org/ en/what-we-do/ending-violence-against-women/facts-and-figures (1.10.2018).

UNESCO, UN Women (2016), Global Guidance on Addressing School-Related Gender-Based Violence. New York, United Nations Educational, Scientific and Cultural Organization, UN Women, http://unesdoc.unesco.org/images/0024/002466/246651E.pdf (1.10.2018).

Unger R., Saundra C. (2002), Seksizm: perspektywa zintegrowana. W: B. Wojciszke (red.), Kobiety i mężczyźni: odmienne spojrzenia na różnice. Gdańsk, GWP.

UNFPA (2010), Adolescent boys and young men. Engaging them as supporters of gender equality and health and understanding their vulnerabilities. Washington, D.C., New York City, UNFPA, https://www.unfpa.org/sites/default/files/pub-pdf/Adolescent_Boys_and_Young_MenSINGLE_PAGES-web.pdf (1.10.2018).

UNHCR (2011), Action against Sexual and Gender-Based Violence: An Updated Strategy. UNHCR Division of International Protection. http://www.refworld.org/docid/4e01ffeb2.html (1.10.2018).

UNICEF (2010), Working For An Equal Future. UNICEF Policy on Gender Equality and the Empowerment Girls and Women. United Nations Children's Fund, https:/www.unicef.org/gender/ files/Working_for_an_Equal_Future_UNICEF_Gender_Policy_2010.pdf (1.10.2018).

WHO (2005), WHO multi-country study on women's health and domestic violence against women: Summary report of initial results on prevalence, health outcomes and women's responses. Geneva, World Health Organization, http://www.who.int/gender/violence/who_multicountry_study/ Introduction-Chapter1-Chapter2.pdf (1.10.2018).

WHO (2009), Strategy for integrating gender analysis and actions into the work of WHO Department of Gender. Geneva, World Health Organization, http://www.who.int/gender/GM_strategy_ jun08.pdf (1.10.2018). 